\title{
Sistem Informasi Monitoring Proses Pembelajaran di STMIK STIKOM Indonesia
}

\author{
I Putu Adi Pratama*1, Anak Agung Gede Bagus Ariana ${ }^{2}$ \\ ${ }^{1,2}$ Teknik Informatika, STMIK STIKOM Indonesia, Bali, Indonesia \\ e-mail: ${ }^{1}$ putudipa@gmail.com, ${ }^{2}$ gungariana@yahoo.com
}

\begin{abstract}
Abstrak
Satuan Acara Perkuliahan (SAP) terdiri dari penentuan tujuan belajar, materi yang akan dibahas, bagaimana cara penyajiannya, media penunjang serta sumber belajar yang dapat digunakan. Pada setiap akhir kegiatan belajar mengajar, untuk keperluan monitoring dan evaluasi, tenaga pengajar diharuskan menuliskan realisasi SAP dalam sebuah jurnal ajar. Di STMIK STIKOM Indonesia, proses penulisan jurnal ajar ini dilakukan secara manual. Dosen mengisikan materi yang diberikan di kelas pada sebuah jurnal ajar. Proses yang dilakukan secara manual mengakibatkan proses monitoring dan evaluasi belum bisa dilakukan secara berkala. Pada penelitian ini dikembangkan sebuah sistem monitoring proses belajar mengajar di STMIK STIKOM Indonesia berbasis Web. Dari pengujian yang dilakukan didapat hasil, sistem yang dibangun dapat memudahkan dosen koordinator matakuliah untuk melakukan monitoring terhadap jalannya proses belajar mengajar. Selain itu sistem yang dibangun juga dapat memudahkan dosen koordinator matakuliah di dalam melakukan proses rekapitulasi terhadap kesesuaian antara SAP dengan realisasi SAP yang dituliskan oleh dosen pengampu matakuliah.
\end{abstract}

Kata kunci-Sistem Monitoring, Satuan Acara Perkuliahan, Jurnal Ajar

Abstract

The Lecture Program Unit (SAP) consists of determining learning objectives, the material to be discussed, how to present it, supporting media and learning resources that can be used. At the end of each teaching and learning activity, for the purposes of monitoring and evaluation, teaching staff are required to write SAP realization in a teaching journal. At STMIK STIKOM Indonesia, the process of writing this teaching journal is done manually. The lecturer filled out the material given in class in a teaching journal. The process is done manually resulting in the process of monitoring and evaluation can not be done regularly. In this research, a Web-based monitoring system for teaching and learning process was developed in STMIK STIKOM Indonesia. From the test results obtained, the system built can facilitate lecturer coordinator lecturers to monitor the course of the teaching and learning process. In addition, the system built can also facilitate lecturer coordinator lecturers in conducting the recapitulation process of the suitability of SAP with the realization of SAP written by lecturers supporting courses

Keywords-Monitoring System, Lecture Program Unit, Teaching Journal

Received August $1^{\text {st }}$, 2019; Revised September 15 ${ }^{\text {th }}$, 2019; Accepted September 25 ${ }^{\text {th }}, 2019$ 


\section{PENDAHULUAN}

Pengajaran merupakan salah satu bagian dari Tri Dharma Perguruan Tinggi. Pengajaran yang dilakukan di perguruan tinggi mengacu pada Silabus dan Satuan Acara Perkuliahan (SAP). Silabus merupakan penjabaran dari kurikulum yang berisikan sinopsis, deskripsi matakuliah, tujuan dan sasaran, pokok bahasan dan referensi. Agar kurikulum dapat diimplementasikan dengan baik dalam perkuliahan, maka silabus perlu dikembangkan menjadi Satuan Acara Perkuliahan. Satuan Acara Perkuliahan memuat Tujuan Instruksional Umum (TIU) dan Tujuan Instruksional Khusus (TIK).

STIMIK STIKOM Indonesia sebagai perguruan tinggi yang sudah berdiri selama tujuh tahun telah mengalami perubahan kurikulum. Dengan jumlah mahasiswa mencapai 2000 mahasiswa (student body) maka diperlukan suatu mekanisme untuk memonitoring proses pengajaran. Dalam rangka memenuhi kualitas pembelajaran yang baik diperlukan suatu prosedur yang mengatur proses pembelajaran. Adapun prosedur pembelajaran telah diatur dalam prosedur ISO 2008.

Proses pengajaran di STMIK STIKOM Indonesia (STIKI) melibatkan mahasiswa, dosen pengampu, koordinator mata kuliah dan Kepala Program Studi. Adapun jumlah pertemuan dalam satu semester adalah sebanyak enam belas pertemuan. Dosen mengajar sesuai dengan Satuan Acara Perkuliahan (SAP) yang sudah ditetapkan. Masing-masing mata kuliah memiliki koordinator matakuliah yang bertugas melakukan pengecekan kesesuaian antara materi yang diberikan oleh dosen pengampu matakuliah dengan SAP. Proses pengecekan idealnya dilakukan secara berkala. Hal ini untuk memastikan semua proses pembelajaran termonitor dengan baik.

Permasalahan yang terjadi adalah jumlah paralel kelas untuk tiap matakuliah adalah cukup banyak. Hal ini menyebabkan proses monitoring secara manual memakan waktu yang tidak sedikit. Koordinator matakuliah harus mengambil berkas jurnal ajar yang ada di bagian akademik kemudian melakukan pengecekan pokok bahasan yang dituliskan oleh dosen pengampu. Permasalahan lain yang timbul yaitu, proses monitoring baru bisa dilakukan di akhir semester. Keterlambatan pelaporan, mengakibatkan informasi menjadi kurang relevan. Pengembangan sistem informasi diperlukan dalam mengatasi permasalahan tersebut. Sistem informasi dapat digunakan pada penentuan kelas unggul dengan k-means [1], pembuatan e-government [2], penentuan keputusan pada sistem pendukung keputusan [3] dan penerapan pada sistem informasi geografis [4], serta hal lainnya yang dalam hal ini adalah monitoring proses pembelajaran.

Pada penelitian ini dikembangkan sebuah sistem monitoring berbasis komputer yang dapat digunakan untuk mengganti proses penulisan dan pengecekan jurnal ajar secara manual yang sebelumnya dilakukan baik oleh dosen pengampu atau koordinator mata kuliah. Melalui sistem ini dosen pengampu dapat menginput pokok-pokok bahasan yang telah diajar serta memberi masukan untuk perbaikan SAP. Koordinator matakuliah secara mudah dapat memonitor kesesuaian pokok bahasan yang diajarkan oleh dosen pengampu dengan SAP tanpa perlu untuk mengambil berkas jurnal ajar ke bagian akademik.

\section{METODE PENELITIAN}

Sistem adalah kumpulan dari elemen-elemen berupa data, jaringan kerja dari prosedurprosedur yang saling berhubungan dan berinteraksi sebagai satu kesatuan untuk mencapai tujuan/sasaran tertentu yang sama [5]. Sebuah sistem terdiri atas bagian-bagian atau komponen terpadu untuk satu tujuan [6]. Pengertian lainnya dari Sistem sebagai kumpulan komponen atau jaringan kerja dari prosedur-prosedur yang saling berkaitan dan bekerja sama membentuk suatu jaringan kerja untuk mencapai tujuan tetentu [7]. Monitoring adalah suatu proses yang dilakukan secara terus menerus yang merupakan bagian yang bersifat integral dari manajemen yang meliputi penilaian yang bersifat sistimatis terhadap kemajuan suatu pekerjaan. Adapun

JSIKTI Vol. 2, No. 1, September 2019: $1-10$ 
beberapa tujuan dari monitoring adalah mengkaji apakah kegiatan-kegiatan yang dilaksanakan telah sesuai dengan rencana, mengidentifikasi masalah yang timbul agar langsung dapat diatasi, melakukan penilaian apakah pola kerja dan manajemen yang digunakan sudah tepat untuk mencapai tujuan serta mengetahui kaitan antara kegiatan dengan tujuan untuk memperoleh ukuran kemajuan [8].

Monitoring adalah seni mengumpulkan informasi yang diperlukan dengan upaya minimum utnuk membuat keputusan pada waktu yang tepat. Informasi ini merupakan data penting dan diperlukan untuk analisis, diskusi, evaluasi, dan pelaporan [9]. Data Flow Diagram menunjukkan bagaimana data bergerak melalui sistem informasi [10].

\subsection{Konteks Diagram}

Konteks diagram dari sistem yang dibangun adalah seperti terlihat pada Gambar 1. Pada Gambar 1 dapat dilihat bahwa data yang diolah oleh sistem bersumber dari tiga entitas luar yaitu admin, dosen pengampu matakuliah dan dosen koordinator matakuliah. Entitas admin akan dapat melakukan pengelolaan lima jenis data yaitu data matakuliah, data sap, data program studi, data pengampu matakuliah dan data koordinator matakuliah. Entitas dosen pengampu matakuliah akan dapat melakukan pengelolaan dua jenis data yaitu data realisasi SAP dan kendala yang ditemui di dalam penerapan SAP dalam proses belajar mengajar di kelas. Yang terakhir, entitas dosen koordinator matakuliah dapat melakukan pengelolaan data kesesuaian SAP dan menerima laporan kesesuaian SAP.

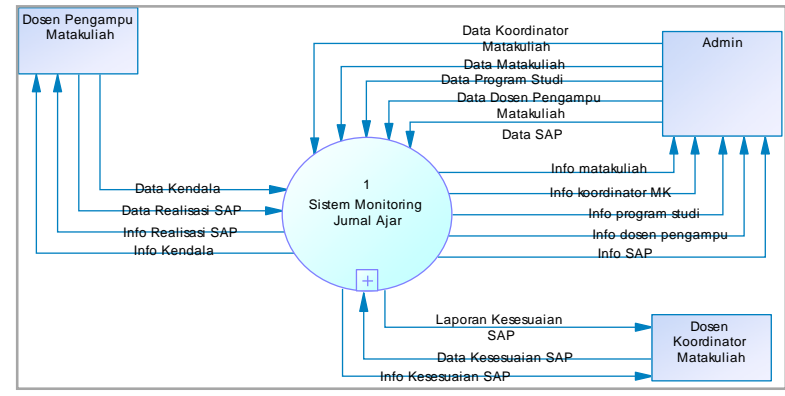

Gambar 1 Diagram konteks sistem

DFD level 0 merupakan penjabaran lebih lanjut dari konteks diagram. Seperti terlihat pada Gambar 2, ada sembilan proses utama yang ada pada sistem yaitu proses mengelola data matakuliah, mengelola data SAP, mengelola data program studi, mengelola data dosen pengampu matakuliah, mengelola data koordinator matakuliah, mengelola data realisasi SAP, mengelola data kendala, mengelola data penilaian SAP dan mengelola data laporan. Selanjutnya data-data yang diolah oleh masing-masing proses tersebut akan disimpan ke dalam enam buah tabel. Keenam tabel tersebut adalah tabel matakuliah, program studi, koordinator matakuliah, pengampu matakuliah, pertemuan dan score. Semua informasi yang selanjutnya ditampilkan dalam sistem juga berasal dari tabel-tabel yang disebutkan tadi.

\subsection{DFD Level 1}

DFD level 1 merupakan penjabaran lebih lanjut dari proses-proses yang ada pada DFD level 0 . Ada empat proses utama yang umumnya ada pada DFD level 1, yaitu proses memasukkan data, merubah data, menghapus dan mencari data dari basis data.

DFD level 1 seperti terlihat pada Gambar 3 merupakan gambaran dari proses-proses yang terjadi dalam proses mengelola data koordinator matakuliah. Dari gambar dapat dilihat terdapat tiga proses yaitu proses tambah, ubah, dan cari data koordinator matakuliah. 


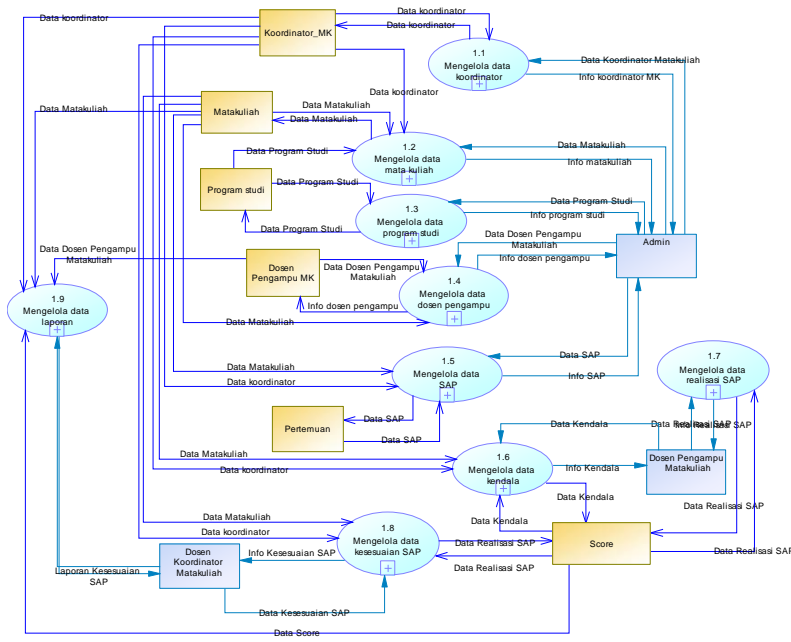

Gambar 2 DFD level 0 sistem

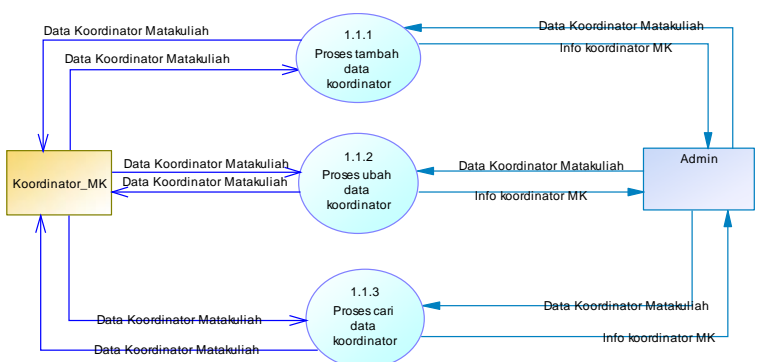

Gambar 3 DFD level 1 proses kelola data koordinator matakuliah

DFD level 1 seperti terlihat pada Gambar 4 merupakan gambaran dari proses-proses yang terjadi dalam proses mengelola data matakuliah. Pada Gambar 8 dapat dilihat bahwa pada proses mengelola data matakuliah terdapat empat proses yaitu menambah, mengubah, dan mencari data matakuliah.

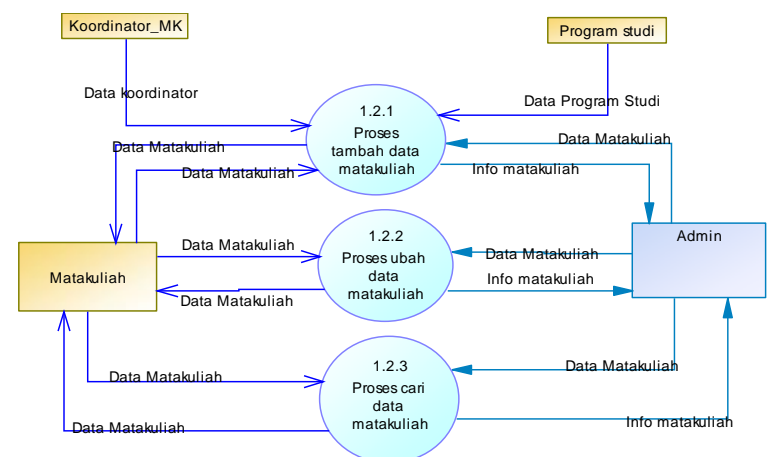

Gambar 4 DFD level 1 proses kelola data matakuliah

DFD seperti terlihat pada Gambar 5 merupakan DFD level 1 dari proses mengelola data program studi. Proses mengelola data program studi terdiri dari dua proses yaitu tambah dan ubah data program studi.

Pada Gambar 6 merupakan DFD level 1 dari proses mengelola data dosen pengampu matakuliah. Pada proses ini terdapat empat proses yaitu tambah, ubah, hapus dan cari data pengampu matakuliah.

Gambar 7 merupakan DFD level 1 dari proses mengelola data SAP. Pada proses mengelola data SAP terdapat empat proses yaitu tambah, ubah, hapus dan cari data SAP. 


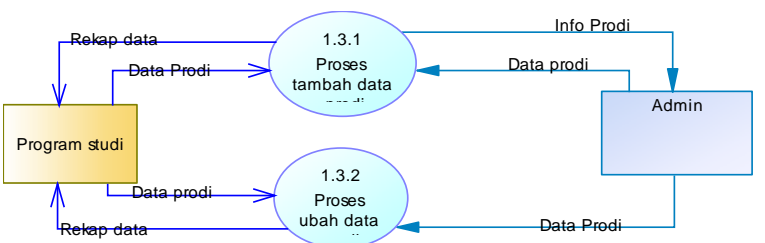

Gambar 5 DFD level 1 proses kelola data program studi

Gambar 8 merupakan DFD level 1 dari proses mengelola data kendala. Proses mengelola data kendala terdiri proses tambah dan ubah data kendala.

Gambar 9 merupakan DFD level 1 dari proses kelola data realisasi SAP. Terdapat dua proses dalam proses kelola data realisasi SAP ini yaitu proses tambah dan ubah data realisasi SAP.

Gambar 10 menunjukkan proses mengelola laporan kesesuaian SAP. Proses ini terdiri dari dua proses utama yaitu proses mengunduh rekap evaluasi kesesuaian SAP dan proses melihat penilaian SAP

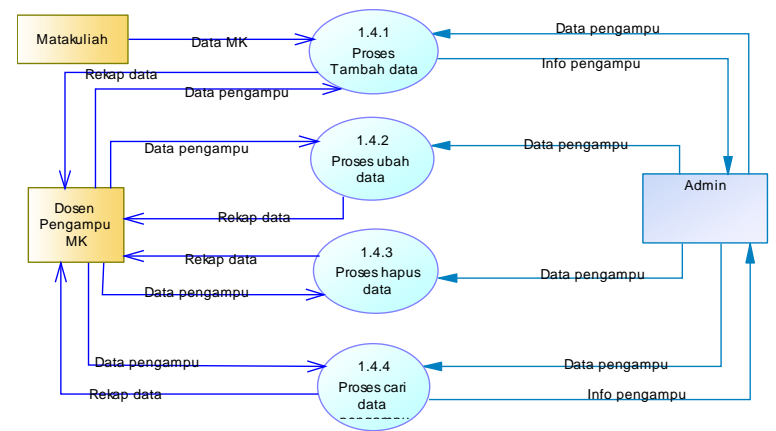

Gambar 6 DFD level 1 proses kelola data pengampu matakuliah

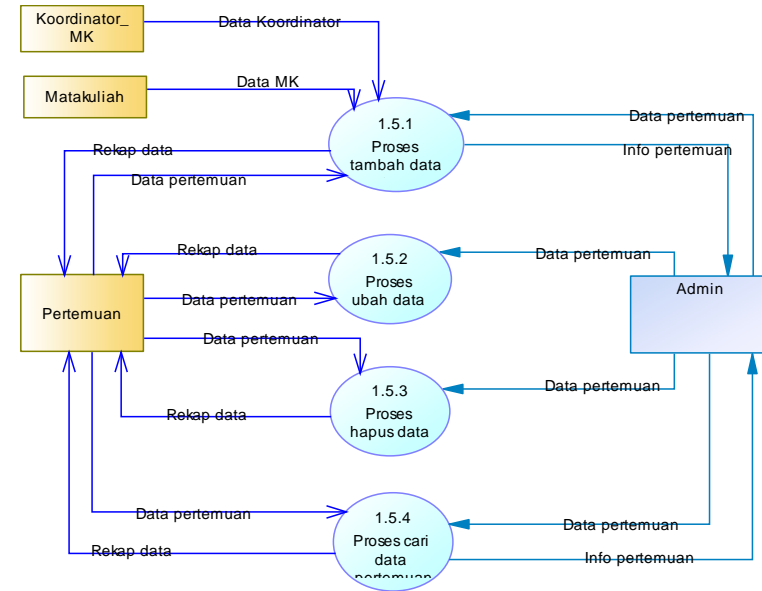

Gambar 7 DFD level 1 proses kelola data SAP

\section{3 Rancangan Basis Data}

Rancangan basis data sistem monitoring jurnal ajar dapat dilihat pada Gambar 11. Basis data sistem monitoring akan terdiri dari 8 tabel, yaitu tabel user, dosen, jurusan, koordinator matakuliah, pengampu matakuliah, penilaian SAP, matakuliah dan pertemuan. Hubungan antara tabel yang terjadi adalah seperti terlihat pada Gambar 4. 


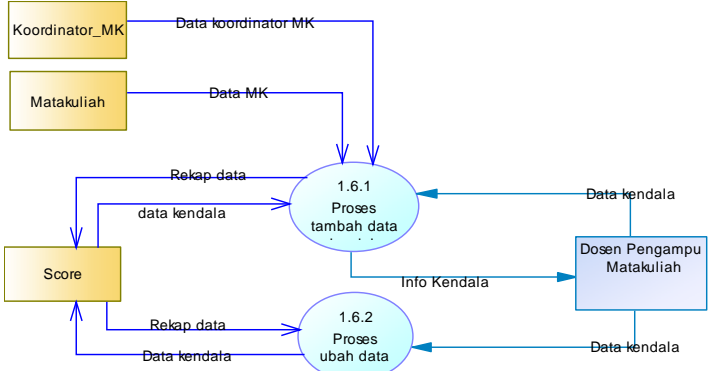

Gambar 8 DFD level 1 proses kelola data kendala

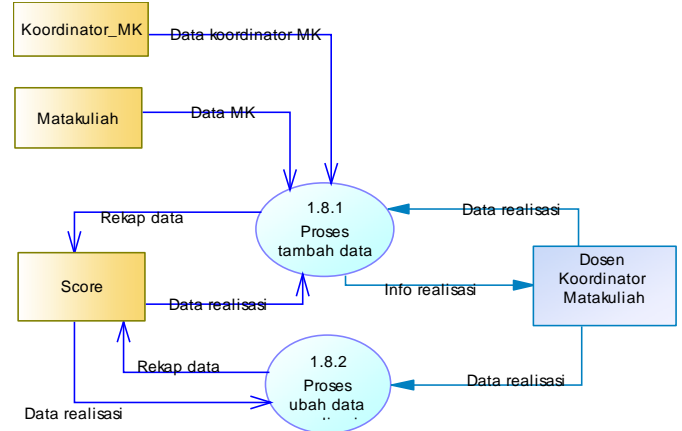

Gambar 9 DFD level 1 proses kelola data kesesuaian SAP

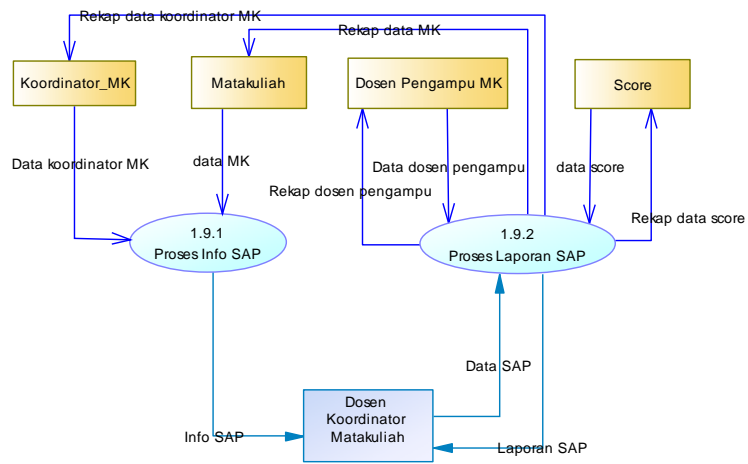

Gambar 10 DFD level 1 proses kelola data laporan

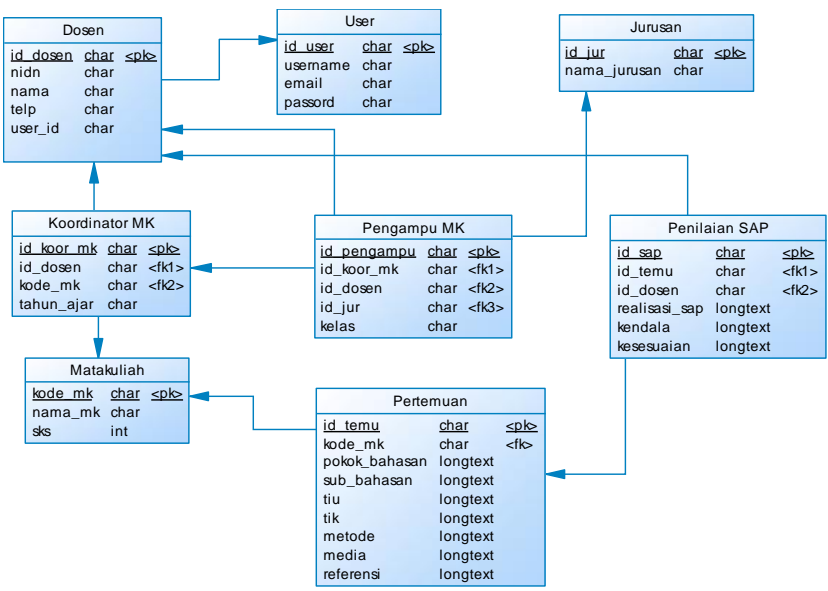

Gambar 11 Rancangan basis data sistem 


\section{HASIL DAN PEMBAHASAN}

\subsection{Halaman Pengguna Admin}

Pengguna admin akan memiliki kemampuan untuk melakukan pengelolaan data master yaitu data master mata kuliah, dosen dan program studi. Pada halaman pengelolaan master data mata kuliah akan terdapat tombol edit SAP yang akan membawa pengguna admin ke halaman edit SAP. Pada halaman edit SAP, pengguna admin dapat menambahkan atau melakukan perubahan terhadap SAP masing-masing pertemuan dari mata kuliah bersangkutan. Halaman penambahan data SAP dapat dilihat pada Gambar 12.

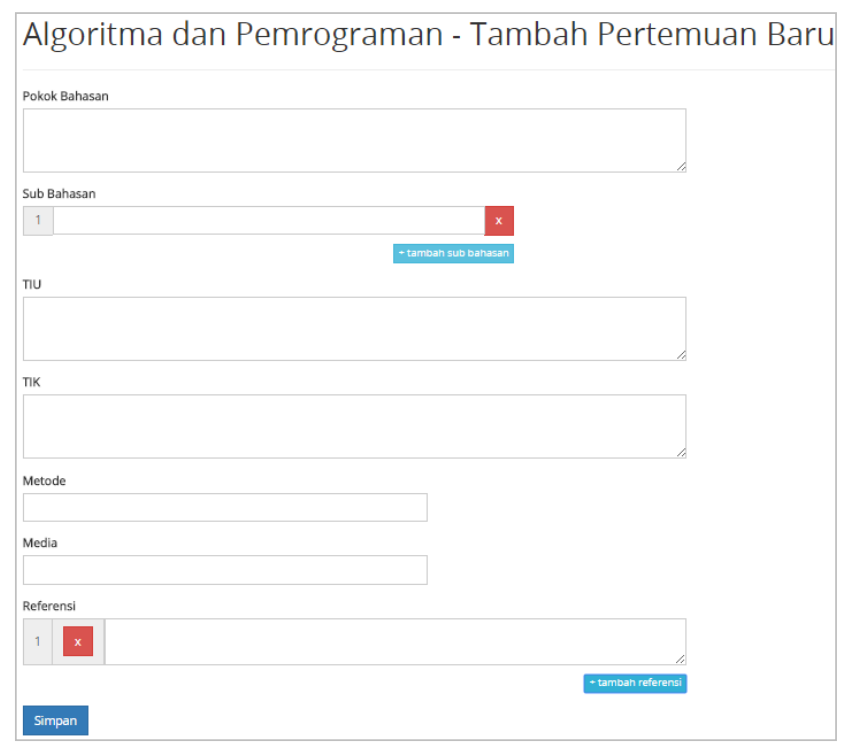

Gambar 12 Halaman penambahan data SAP

Selain dapat melakukan pengelolaan data master, pengguna admin juga akan dapat melakukan proses penentuan pengampu mata kuliah. Halaman penentuan pengampu matakuliah adalah seperti terlihat pada Gambar 13. Penentuan pengampu mata kuliah adalah dilakukan sesuai dengan tahun ajarnya. Matakuliah yang ditampilkan pada tabel yang ada di bagian bawah halaman penentuan pengampu mata kuliah adalah matakuliah-matakuliah yang sebelumnya telah diinputkan pada master data mata kuliah. Untuk menentukan pengampu mata kuliah, admin dapat memilih tombol edit yang ada di bagian kanan halaman. Selanjutnya akan muncul daftar dosen yang dapat dipilih untuk menjadi pengampu mata kuliah bersangkutan.

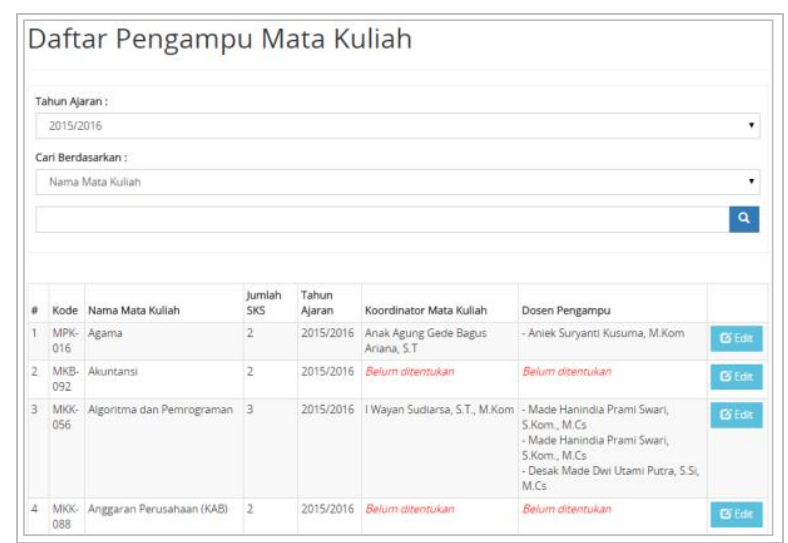

Gambar 13 Halaman penentuan pengampu mata kuliah 


\subsection{Halaman Dosen Pengampu Mata Kuliah}

Untuk keperluan monitoring dan evaluasi, pada setiap pertemuan, dosen pengampu mata kuliah diwajibkan untuk menuliskan realisasi SAP yang diberikan di kelas. Halaman penulisan realisasi SAP bagi dosen pengampu mata kuliah adalah seperti terlihat pada Gambar 14. Selain berisi kolom untuk menuliskan realisasi SAP, pada halaman ini juga berisi kolom untuk mengisikan kendala yang ditemui oleh dosen pengampu di dalam merealisasikan SAP.

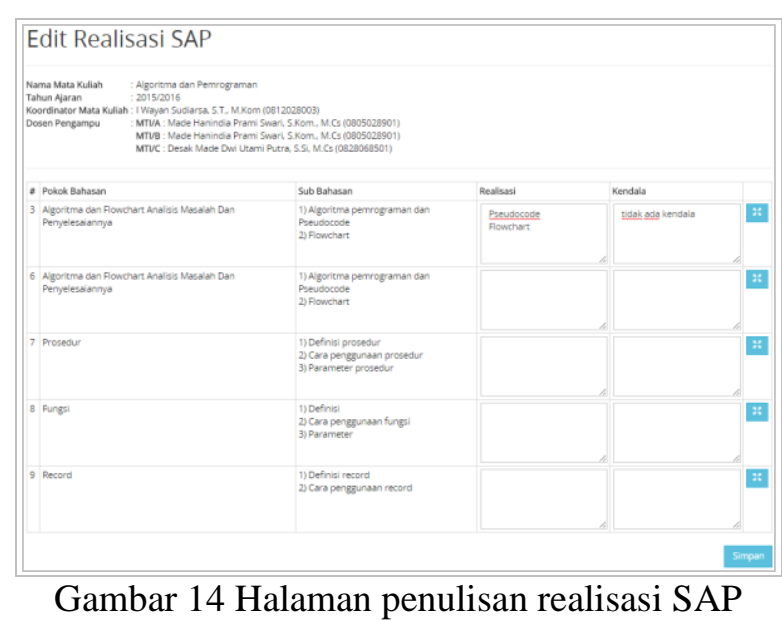

\subsection{Halaman Dosen Koordinator Mata Kuliah}

Koordinator matakuliah dapat melakukan proses penilaian terhadap realisasi SAP yang dituliskan oleh dosen pengampu matakuliah dan mengunduh laporan rekapitulasi kesesuaian SAP. Gambar halaman penilaian realisasi SAP adalah seperti terlihat pada Gambar 15. Pada halaman penilaian realisasi SAP dapat dilihat terdapat informasi mengenai SAP dari matakuliah bersangkutan serta realisasi dan kendala yang diisikan oleh dosen pengampu matakuliah. Dosen koordinator mata kuliah selanjutnya dapat memberikan penilaian dengan memilih nilai "sesuai" atau "tidak sesuai" di combo box yang ada pada kolom kesesuaian.

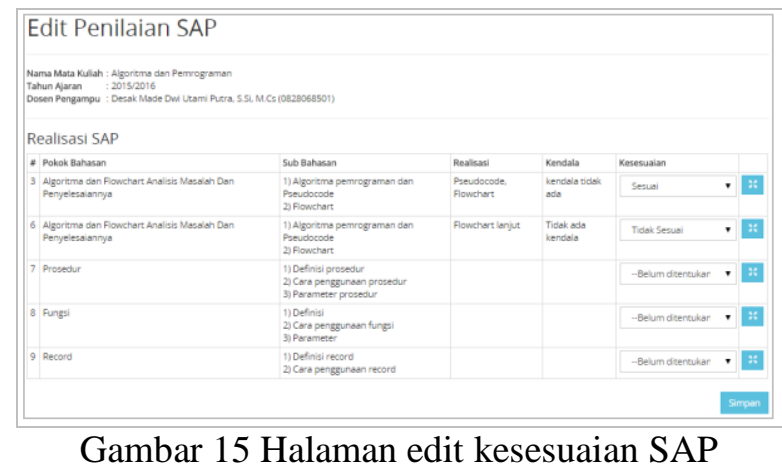

Selain dapat melakukan penilaian terhadap realisasi SAP, pengguna koordinator mata kuliah juga dapat mengunduh laporan berupa rekapitulasi kesesuaian SAP. Rekapitulasi kesesuaian SAP yang diunduh akan berupa file excell. Gambar dari rekapitulasi kesesuaian SAP dapat dilihat pada Gambar 16. Pada laporan rekapitulasi kesesuaian SAP akan terdapat informasi mengenai nama mata kuliah, dosen-dosen yang mengajar matakuliah bersangkutan, penilaian kesesuaian SAP untuk masing-masing pertemuan yang ada, persentase kesesuaian SAP untuk masing-masing dosen pengampu matakuliah dan persentase rata-rata kesesuaian SAP seluruh

JSIKTI Vol. 2, No. 1, September 2019: $1-10$ 
dosen pengampu mata kuliah untuk matakuliah bersangkutan. Seperti terlihat pada Gambar 21, akan terdapat angka 0 atau 1 pada kolom pertemuan. Angka 0 menunjukkan bahwa pada pertemuan tersebut materi yang diajarkan adalah belum sesuai dengan SAP, sementara angka 1 menunjukkan bahwa pada pertemuan tersebut materi yang diajarkan sudah sesuai dengan SAP.

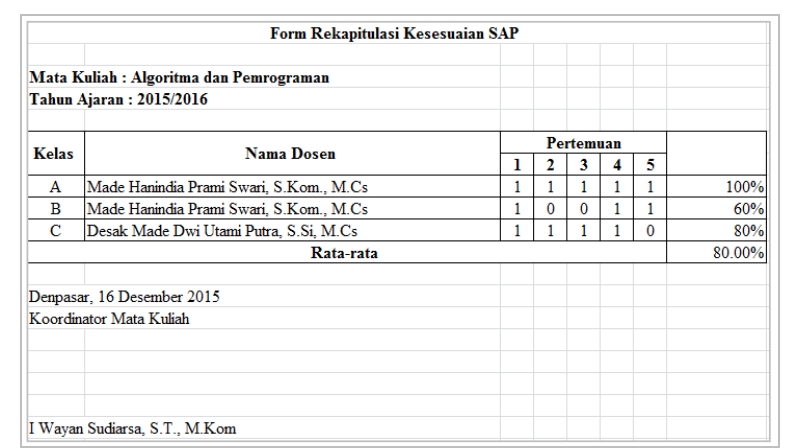

Gambar 16 Form laporan rekapitulasi kesesuaian SAP

\section{KESIMPULAN}

Berdasarkan penelitian yang telah dilakukan, dapat ditarik beberapa kesimpulan yaitu sistem yang dibangun dapat memudahkan dosen koordinator matakuliah untuk melakukan monitoring terhadap jalannya proses belajar mengajar. Sistem yang dibangun dapat memudahkan dosen koordinator matakuliah di dalam melakukan proses rekapitulasi kesesuaian antara SAP dengan realisasi SAP yang dituliskan oleh dosen pengampu matakuliah.

\section{SARAN}

Pada pengembangan selanjutnya aplikasi dapat dikembangkan dengan menggunakan teknologi mobile, sehingga aplikasi dapat diakses dengan baik melalui perangkat mobile.

\section{DAFTAR PUSTAKA}

[1] A. Kusuma dan K. Aryati, "Sistem Informasi Akademik Serta Penentuan Kelas Unggulan Dengan Algoritama K-Means di SMP Negeri 3 Ubud”, jsikti, vol. 1, no. 3, pp. 143-152, Mar. 2019.

[2] P.Sugiartawan, I.D.K.R. Rustina, R.W.S. Insani, "E-Government Media Informasi Alat Kelengkapan Dewan Provinsi Bali dan Media Diskusi Berbasis Website," J. Sist. Inf. dan Komput. Terap. Indones., vol. 2, no. 1, 2018.

[3] I. Pratistha, P. Sugiartawan, U. G. Mada, M. Manajemen, and U. G. Mada, "Sistem Pendukung Keputusan Kelompok Pemilihan E-Commerrce Menggunakan Metode Profile Matching dan BORDA," jsikti, vol. 1, no. 1, 2018.A. Mauko, B. Muslimin, and P. Sugiartawan, ìSistem Pendukung Keputusan Kelompok Dalam Pemilihan Saham Indeks LQ 45 Menggunakan Metode,” J. Sist. Inf. dan Komput. Terap. Indones., vol. 1, no. 1, pp. 25-34, 2018.

[4] D. Dwi Utami Putra dan P. Sugiartawan, "Sistem Informasi Geografis Tata Guna Lahan di Kabupaten Sleman”, jsikti, vol. 1, no. 3, pp. 175-184, Mar. 2019.

[5] Maniah dan D. Hamidin, "Analisis \& Perancangan Sistem Informasi," Yogyakarta: Deepublish, 2017.

[6] T. Sutabri, "Konsep Sistem Informasi,” Yogyakarta: CV. ANDI OFFSET, 2012. 
[7] M. Muslihudin dan Oktafianto, "Analisis \& Perancangan Sistem Informasi,”, Yogyakarta: CV. ANDI OFFSET, 2016.

[8] Mudjahidin dan N.D.P. Putra, "Rancang Bangun Sistem Informasi Monitoring Perkembangan Proyek Berbasis Web Studi Kasus Di Dinas Bina Marga Dan Pemantusan,” Jurnal Teknik Industri, Vol. 11, No. 1, pp. 75-83, 2010.

[9] P. Gudda, "A Guide to Project Monitoring \& Evaluation," Bloomington: AuthorHouse, 2011.

[10] G. B. Shelly and H. J. Rosenblatt, "Systems Analysis and Design," $8^{\text {th }}$ ed, Boston: Cengage Learning, 2010. 